J. Perinat. Med. 16 (1988)

\title{
Effect of maternal intrapartum glucose therapy on neonatal blood glucose levels and neurobehavioral status of hypoglycemic term new- born infants
}

\author{
Sunit Singhi \\ Department of Child Health, University of the West Indies, Kingston, Jamaica \\ (West Indies)
}

\section{Introduction}

Experimental studies had shown that infusions of glucose to women prior to delivery causes maternal and transplacental hyperglycemia $[2,5,12$, $17,24]$ and an increase in fetal insulin levels [2, 5, $15,17,24]$. Prospective studies of infants whose mothers received glucose infusion during induction of epidural or general anesthesia prior to normal or cesarean section delivery, have also shown a rapid postnatal fall in blood glucose level of such infants $[11,16]$. Yet, glucose containing fluids are often administered to women during labor for hydration, for prevention of ketosis or for oxytocin therapy. This prospective study was designed to determine changes in blood glucose at 1 and 2 hours of age in term infants whose mothers received glucose therapy during the course of spontaneous or oxytocin induced labor prior to a normal delivery. Neurobehavioral changes, if any, associated with neonatal hypoglycemia were also studied.

\section{Material and methods}

The study comprised two groups of 45 newborn infants and their mothers who delivered at the University Hospital of the West Indies between Spetember 1 to October 31, 1983. Mothers of 23 infants had received varying amounts of intravenous infusion of glucose solution during labor for hydration or for oxytocin therapy (study group) while those of other 22 infants did not receive any intravenous fluid therapy (control group). All the decisions regarding maternal fluid and glucose

\section{Curriculum vitae}

Dr. SunIt SINGHI qualified as a pediatrician in 1976, from All India Institute of Medical Sciences, New Delhi, India. He has served on the faculty of medical colleges in India, and University of the West Indies, Kingston, Jamaica (1981-84). His research covers broad areas of perinatalogy and neonatalogy and he has published 67 research papers. Significant contributions include the effect of maternal intrapartum fluid and oxytocin therapy on newborn infants. He is a recipient of the Manchanda Award from the Indian Academy of Pediatrics for his research in neonatalogy for 1978. Currently he is working on body water changes in newborn infants.

therapy were taken by attending obstetrician and were in no way influenced by the study. Fluid intake of mothers in the control group consisted of small sips of water.

Only singleton infants who were delivered vaginally at term (gestation 37-41 weeks) with a vertex presentation, and had an Apgar score of 7 or more at 5 minutes were eligible for inclusion in the study. Infants who had fetal distress, Apgar score $<7$ at 5 minutes, congenital anomalies, or whose mothers had diabetes mellitus, toxemia of pregnancy, chronic renal disease, or any other 
known metabolic or endocrine problems were excluded. For the sake of convenience of sample processing, and to facilitate timely neurobehavioral examination, it was decided to study only those infants, who were delivered between $8 \mathrm{~A}$. M. to $6 \mathrm{P}$. M. Informed consent was obtained from the mothers to study their infants. The research protocol was approved by the Hospital Ethical Committee.

Maternal and perinatal data, and the details of maternal fluid and glucose therapy during labor were recorded on a data form. Gestational age of the newborn infants was calculated from the mothers' last menstrual period, and also assessed by physical and neurological criteria. No discrepancy was observed between the calculated and the assessed gestational age in any of the infants. Feeding of the newborn infants was started after 2 hours of age.

Maternal and umbilical cord venous blood samples at the time of delivery, and neonatal capillary blood samples by heel-sticks at one and two hours of age, were taken for determination of blood glucose levels (by Glucose analyzer).

Neurobehavioral examination was performed on all the babies at one and two hours of age, just before the heel-sticks, using Scanlon's Early Neonatal Neurobehavioral Scale (ENNS) (SCANLON et al. [18]). At the same time, the known clinical signs of hypoglycemia and any other abnormal signs were carefully looked for. All the examinations were performed by the same observer (SS), who was blind to the infant's group, and his blood glucose values at the time of the examination.

The statistical methods used were chi-square test, t-test, or linear correlation analysis, depending on the nature of the data.

\section{Results}

The two groups of infants were similar with respect to maternal and perinatal variables, gestational age, and birth weight (Table I).

The duration of intravenous fluid therapy in the study group mothers ranged between 1 to 22 hours (mean 4.8, SD 5.5 hours) and the total volume of fluid between 125-2050 ml (mean 845, SD 533 $\mathrm{ml})$. About $50 \%$ of all the fluid was $5 \%$ glucose solution, and another $50 \%$ was a $10 \%$ solution; 3 mothers also received $50 \mathrm{ml}$ each of $50 \%$ glucose
Table I. Maternal and neonatal variables of infants in the study and the control group

\begin{tabular}{lcc}
\hline Variables & $\begin{array}{l}\text { Study } \\
\text { group } \\
(\mathrm{n}=23)\end{array}$ & $\begin{array}{l}\text { Control } \\
\text { group } \\
(\mathrm{n}=22)\end{array}$ \\
\hline Maternal & & \\
Age (yrs) & $25.3(5.6)^{*}$ & $26.6(3.2)$ \\
$\begin{array}{l}\text { Primigravida } \\
\text { Bloos pressure }\end{array}$ & $43 \%$ & $36 \%$ \\
$\quad$ Systolic & $120(13)$ & $120(8)$ \\
$\quad$ Diastolic & $74(10)$ & $72(12)$ \\
$\begin{array}{l}\text { Duration of labor } \\
\quad \text { I stage (hrs) }\end{array}$ & $7.2(3.9)$ & $6.1(3.2)$ \\
$\quad$ II stage (min) & $31(16)$ & $24(8)$ \\
\hline
\end{tabular}

Neonatal

\begin{tabular}{lcc}
$\begin{array}{l}\text { Apgar score } \geq 7 \\
\text { at one min }\end{array}$ & 21 & 20 \\
at 5 min & 23 & 22 \\
Gestational age (days) & $280(9)$ & $277(11)$ \\
Birth weight (g) & $3307(417)$ & $3164(276)$ \\
\hline
\end{tabular}

* Mean (SD)

solution. The mothers of the study group infants thus received between $12.5-150 \mathrm{~g}$ (mean 65, SD $41 \mathrm{~g})$ glucose during labor, at a rate ranging between 4.5-75 g/hour (mean 22.9, SD 15.5). Oxytocin $(2.5-10 \mathrm{U})$ was received by nine mothers in the study group; in three for induction, and in six for augmentation of labor.

As shown in Figure 1, mean maternal and cord blood glucose levels at the time of delivery were significantly higher in the study group as compared to the control group. Cord blood glucose levels were about $73 \%$ and $71 \%$ of the maternal glucose levels in the study and the control group respectively, and the two levels showed a very good correlation $(\mathrm{r}=0.86, \mathrm{p}<0.001)$ (Figure 2). A significant correlation was seen between the amount of maternal glucose infusion per hour and maternal and cord blood glucose levels (Figure 3). The total amount of glucose received by mother did not show similar relationship with the blood glucose levels.

Mean blood glucose level at the age of 1 hour were similar in the two groups (Figure 1) but the postnatal fall in the glucose level, between birth and one hour of age, was significantly higher in the study group infants (mean $3.6, \mathrm{SD} 1.7 \mathrm{mmol} /$ 1) as compared to the control infants (mean 1.3, SD $1.0 \mathrm{mmol} / \mathrm{l})(\mathrm{p}<0.01)$. 


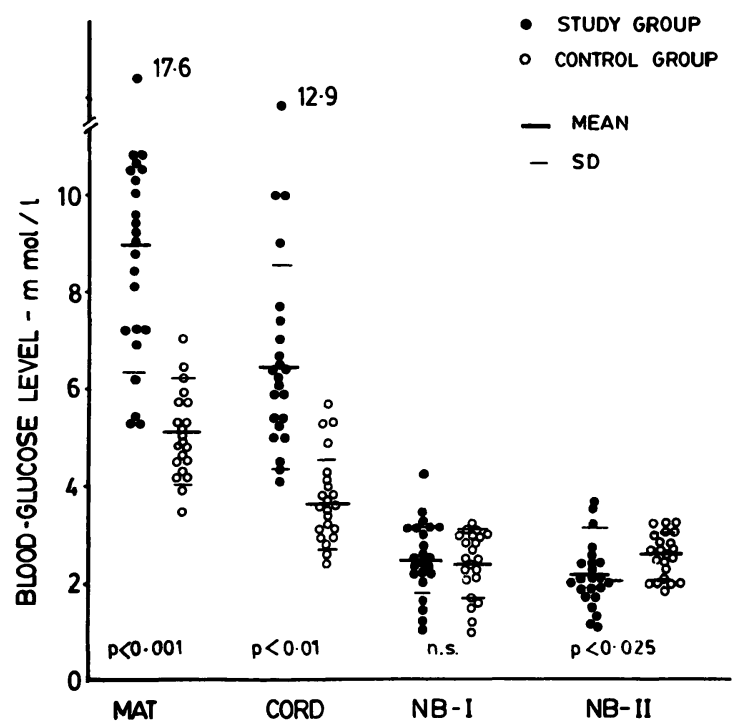

Figure 1. Glucose levels in maternal (MAT), umbilical cord, and neonatal capillary blood samples at $1 \mathrm{~h}$ (NB I), and $2 \mathrm{~h}$ (NB II) of age, in study (O) and control (O) infants.

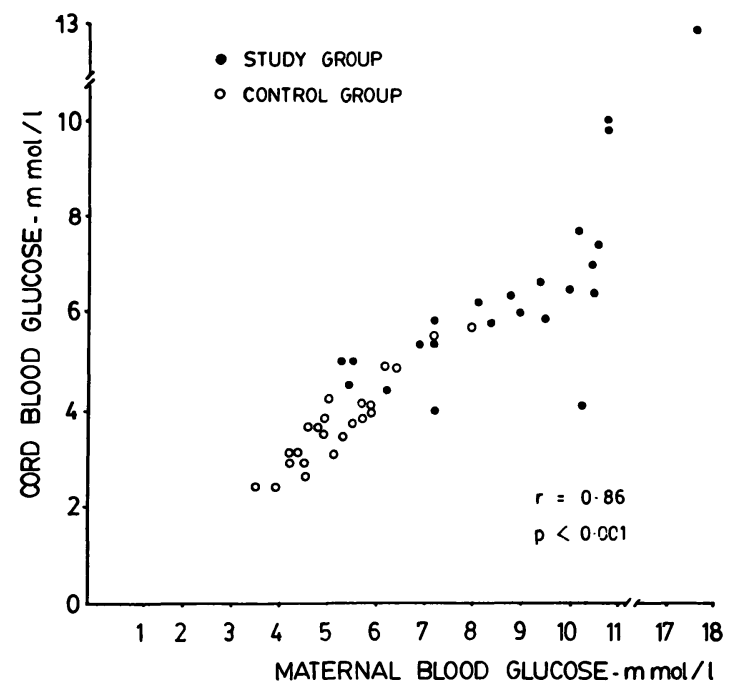

Figure 2. Correlation between maternal and umbilical cord blood glucose levels at the time of delivery, in study $(O)$ and control $(O)$ groups.

AT 2 hours the mean blood glucose level was significantly lower in the study infants as compared to the controls (Figure 1). Most of the study infants $(17 / 23 ; 74 \%)$ showed a further fall in their blood glucose levels between 1 and 2 hours of age;

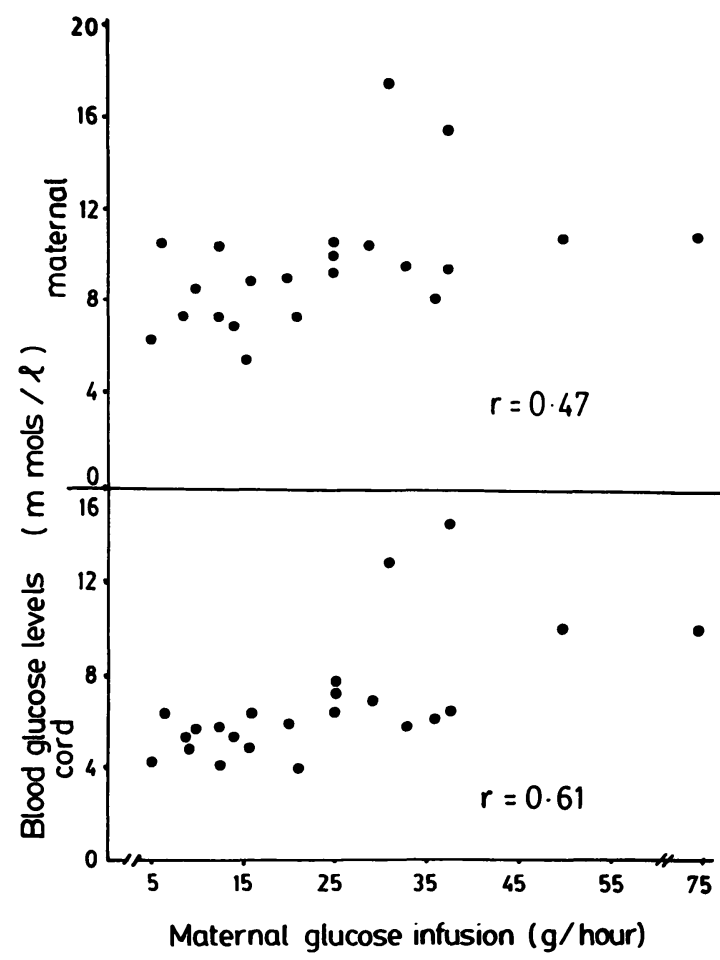

Figure 3. Correlation between maternal glucose infusion rate $(\mathrm{g} / \mathrm{hour})$ and cord blood glucose level in the study group.

only 4 showed a rise and the levels remained unchanged in two infants. In this group mean (SD) fall in the blood glucose levels between 1 and 2 hours was $0.36(0.67) \mathrm{mmol} / \mathrm{l}$. In contrast to this, $16(73 \%)$ of the control infants demonstrated an increase in their blood glucose levels between 1 and 2 hours of age (mean 0.22 , SD 0.36 $\mathrm{mmol} / \mathrm{l})(\mathrm{p}<0.05)$.

The incidence of hypoglycemia in the two groups was similar at 1 hour of age (Table II). But at 2 hours of age, study infants showed a 3 times higher incidence of hypoglycemia, defined as blood glucose level of $2.2 \mathrm{mmol} / 1$ or less (SEXSON [19]) as compared to control infants. Severe hypoglycemia (glucose level $\leq 1.6 \mathrm{mmol} / \mathrm{l}$ ) at 2 hours of age was seen in the study group infants only. Symptoms of hypoglycemia, such as jitteriness/lethargy were seen in five infants in the study (two at 1 hour, two at 1 and 2 hours, and one at 2 hours) and two infants in the control group (both at 1 hour). None of these infants had seizures. All the symptomatic infants had a blood glucose level of $1.6 \mathrm{mmol} / 1$ or less. 
Table II. Incidence of neonatal hypoglycemia at one and two hours of age in study and control infants

\begin{tabular}{lll}
\hline $\begin{array}{l}\text { Neonatal blood } \\
\text { glucose levels }\end{array}$ & $\begin{array}{l}\text { Study } \\
\text { groups } \\
(\mathrm{n}=23)\end{array}$ & $\begin{array}{l}\text { Control } \\
\text { group } \\
(\mathrm{n}=22)\end{array}$ \\
\hline
\end{tabular}

$\begin{array}{lll}\text { At one hour } & & \\ \text { (i) } \leq 2.2 \mathrm{mmol} / 1 & 8(35 \%) & 7(32 \%) \\ \text { (ii) } \leq 1.6 \mathrm{mmol} / 1 & 4(17 \%) & 4(17 \%)\end{array}$

At two hours

$\begin{array}{ccl}\text { (i) } \leq 2.2 \mathrm{mmol} / 1 & 14(61 \%)^{*} & 5(22.7 \%) \\ \text { (ii) } \leq 1.6 \mathrm{mmol} / 1 & 4(17 \%) & 0\end{array}$

* $\mathrm{p}<0.025 ; \chi^{2}$ test

Table III. Mean (SD) ENNS scores with respect to normoglycemia $(\geq 2.3 \mathrm{mmol} / \mathrm{l})$ and hypoglycemia $(\geq 2.2 \mathrm{mmol} / \mathrm{l})$ (Data from 45 infants, ENNS evaluation done at 1 and 2 hours of age)

\begin{tabular}{lll}
\hline ENNS variables & $\begin{array}{l}\text { Hypo- } \\
\text { glycemia } \\
(\mathrm{n}=34)\end{array}$ & $\begin{array}{l}\text { Normo- } \\
\text { glycemia } \\
(\mathrm{n}=56)\end{array}$ \\
\hline $\begin{array}{l}\text { Response to pin prick } \\
\text { Pin prick response decrement }\end{array}$ & $2.4(0.8)$ & $2.6(0.7)$ \\
$\quad$ score & $4.9(1.4)^{+}$ & $5.6(1.7)$ \\
Tone (composite score & & \\
$\quad$ on 4 items) & $5.4(1.5)^{*}$ & $6.9(1.6)$ \\
Rooting & $1.3(0.9)$ & $1.2(0.5)$ \\
Sucking & $1.1(0.9)$ & $1.5(0.8)$ \\
Moro's response & $2.1(0.5)$ & $2.0(0.4)$ \\
Moro's response-maximal & $2.6(0.7)$ & $2.3(0.6)$ \\
Moro's response-extinction & $6.9(1.8)^{*}$ & $5.4(2.2)$ \\
Response to light-decrement & $3.8(1.2)^{*}$ & $3.0(1.3)$ \\
Response to sound & $1.2(0.6)$ & $1.1(0.8)$ \\
Placing response & $2.0(1.2)$ & $2.3(0.7)$ \\
Alertness state & $2.65(1.0)$ & $2.0(0.93)$ \\
\hline
\end{tabular}

$* \mathrm{p}<0.001$, by t-test

$+\mathrm{p}<0.05$

Neurobehavioral examination: A total of 90 ENNS evaluations were performed on 45 infants. No difference was seen between the mean scores obtained by the study and control infants on the various items of ENNS. The data from the two groups was pooled for further analysis with respect to blood glucose levels at the time of examination. Several significant differences were observed between the mean ENNS scores obtained by the infants who had a blood glucose level of $2.2 \mathrm{mmol} / 1$ or less (hypoglycemic) and those who had a level of $2.3 \mathrm{mmol} / 1$ or more (normoglycemic) (Table III). The hypoglycemic infants had a significantly lower mean score on muscle tone and higher mean score on Moro's response extinction and light response decrement as compared to the normoglycemic infants $(\mathrm{p}<0.001)$. The mean score on pin prick response decrement was also somewhat lower in the hypoglycemic infants.

We arbitrarily labelled extinction of Moro's response in less than 5 attempts as early, and in 5 or more as delayed. Eighty-four per cent of all the hypoglycemic episodes were accompanied by a delayed extinction of Moro's response. In contrast only $31 \%$ of normoglycemic babies had a delayed extinction of Moro's response. A low muscle tone score of 5 or less was seen with $53 \%$ of hypoglycemic episodes; as compared to this only $11 \%$ of the normoglycemic episodes were associated with a low muscle tone score. A low muscle tone score (5 or less), together with a nonextinction of maximal Moro's response even after 5 attempts, was seen in $44 \%$ of hypoglycemic infants, as compared to only $2 \%$ of the normoglycemic infants.

\section{Discussion}

The study clearly demonstrates that the intrapartum infusion of glucose solution to mothers during the course of normal or induced labor affects neonatal blood glucose levels adversely and predisposed the infant to an increased risk of hypoglycemia at two hours of age. These observations are consistent with the findings of previous studies on the infants whose mothers received glucose infusion during induction of epidural or general anaesthesia prior of delivery $[11,16]$ and infants of diabetic mothers [1].

During normal pregnancy, the fetus receives a continuous supply of nutrients for its oxidative metabolism essentially in the form of glucose from maternal blood. At birth this supply is abruptly cut off. Under normal conditions rapid adaptive changes occur to ensure an uninterrupted supply of oxidative fuels from endogenous stores. Important among these changes are breakdown of glycogen accumulated in fetal liver during late pregnancy and initiation of gluconeogenesis (reviewed by KTORZE [13]). The efficiency of these processes depends largely on the plasma concentrations of insulin which falls abruptly, and glucagon, which rise acutely, immediately after birth [13, 14]. An alteration in the normal circulating levels of one 
or both of these hormones in the immediate postnatal period may greatly hamper the metabolic adaptation [13]. Maternal glucose infusion by raising maternal blood glucose level facilitates diffusion of higher amounts of glucose across the placenta to the fetus and causes fetal hyperglycemia $[2,5,17,24]$ which in turn stimulates fetal insulin $[2,9]$ and inhibits glucagon secretion [10]. Thus a significant increase in fetal/cord plasma insulin [4, $11,15]$ and decrease in glucagon levels [3, 11] occurs. These changes in insulin and glucagon levels at birth are expected to increase the glucose utilisation rate, (reviewed by CHEZ [4]), delay hepatic glycogenolysis and gluconeogenesis [13], and thus cause a rapid postnatal fall in the blood glucose levels. The above explains our observation of cord blood hyperglycemia, significant postnatal fall in blood glucose levels and a low blood glucose levels at 2 hours of age in the infants whose mothers had received glucose infusion prior to delivery.

CoRnblath et al. [6] in a retrospective study had shown that among vaginally delivered newborn infants, average blood glucose levels were the lowest in infants whose mothers received intravenous infusion of glucose during labor. MENDIOLA et al. [16] in an uncontrolled study have shown that $11 \%$ of 56 infants, whose mothers received glucose infusion during induction of epidural or general anesthesia, prior to an elective cesarean section or vaginal delivery, had a blood glucose level $\leq 1.6 \mathrm{mmol} / 1$ at one hour of age. KENEPP et al. [11] found that the mean 2 hour blood glucose level in fifteen infants whose mothers received $57.5 \mathrm{~g}$ glucose before an elective cesarean section delivery under epidural anesthesia, was 1.8 (SE 0.22 ) $\mathrm{mmol} / 1$, in contrast to a level of 3.4 (SE 0.2) $\mathrm{mmol} / 1$, in 16 infants whose mothers received only $7.5 \mathrm{~g}$ glucose. Our findings show that an excessive postnatal fall in blood glucose and increased risk of neonatal hypoglycemia, is also present in healthy, normally delivered infants, if mothers receive glucose infusion for oxytocin therapy or for hydration during labor.

\footnotetext{
Abstract

Two groups of 45 term, vaginally delivered infants were studied to determine effect of maternal intrapartum glucose therapy on neonatal blood glucose level at birth and at one and 2 hours of age. Twenty-three infants whose mother received glucose infusion prior to delivery
}

Significant lowering of muscle tone and delayed habituation to various stimuli viz. extinction of Moro's response and pin prick and light response decrement were seen in infants who had blood glucose levels of $2.2 \mathrm{mmol} / \mathrm{l}$ or less. This is in contrast to the findings of MENDIOLA et al. [16] who did not find any significant difference in the ENNS scores of hypoglycemic and normal neonates except better auditory habituation in hypoglycemic infants. However, as the authors themselves pointed out, in their study the neurobehavioral assessment did not coincide with the exact time of hypoglycemia.

We are unable to comment on biological significance of neurobehavioral changes seen in the hypoglycemic infants. Studies have shown that adverse C. N.S. effects from neonatal hypoglycemia may occur beyond the period of hypoglycemia [7]. It is possible that the early neurobehavioral abnormality may be a forerunner of subsequent neurological abnormality in an otherwise asymptomatic hypoglycemic infants. This aspect requires further studies.

Although there are clearly defined indications for glucose infusion during labor, yet the practice is not entirely safe for the newborn infant [8]. Besides causing an alteration in neonatal glucose homeostatis as shown by previous studies and our data, infusions of glucose solution for hydration or oxytocin therapy may also cause fetal and neonatal acidosis [14], transplacental neonatal hyponatremia $[20,23]$ and an increased risk of neonatal jaundice [21] and respiratory distress [22]. Until more definite data is available on the safe dose and rate of glucose infusion during labor, maternal blood glucose level in such mothers should be monitored and kept within physiological limits, to avoid maternal and fetal hyperglycemia and subsequent risk of neonatal hypoglycemia. Blood glucose levels should be monitored in all those infants whose mothers receive glucose infusion prior to delivery, to detect early neonatal hypoglycemia.

(study group) had a significantly higher mean cord blood glucose level, lower 2 hour blood glucose levels and about three times higher incidence of hypoglycemia (glucose level $\leq 2.2 \mathrm{mmol} / \mathrm{l}$ ) as compared to 22 infants whose mothers did not receive any glucose or fluid 
therapy. Neurobehavioral evaluation of the infants at 1 and 2 hour demonstrated, a significant association between hypoglycemia and a low muscle tone score and a delayed habituation to various stimuli. Blood glucose levels must be routinely monitored in infants whose mother receive glucose infusion prior to delivery to detect and treat early neonatal hypoglycemia.

Keywords: Glucose, glucose infusion, hypoglycemia, newborn infant, neurobehavior.

\section{Zusammenfassung}

Auswirkungen einer intrapartalen Glukosegabe an die Mutter auf den neonatalen Blutglukosespiegel und den neurologischen Status bei hypoglykämischen Reifgeborenen

Um den Effekt einer Glukosegabe an die Mutter vor einer Spontangeburt auf die Homöostase des kindlichen Glukosespiegels zu erfassen, wurden die Glukosespiegel im mütterlichen Blut und Nabelschnurblut zum Zeitpunkt der Geburt sowie 1 und $2 \mathrm{~h}$ post partum bei 45 Reifgeborenen bestimmt. 23 Mütter erhielten Glukose intravenös vor der Entbindung (Untersuchungsgruppe), während 22 Mütter ohne Infusion als Kontrollgruppe dienten. Der neurologische Status aller Kinder wurde 1 sowie $2 \mathrm{~h}$ post partum erhoben und mit dem Early Neonatal Neurobehavioural Scale of ScANLON (ENNS) bewertet.

Die Kinder der Glukosegruppe hatten im Vergleich mit der Kontrolle einen signifikant höheren, mittleren Blutglukosespiegel im Nabelschnurblut $(6,5 \mathrm{mmol} / 1$ vs. 3,7 $\mathrm{mmol} / 1$, SD $2,1 \mathrm{mmol} / 1$ vs. $0,9 \mathrm{mmol} / 1, \mathrm{p}<0.01)$. Der Abfall zwischen Geburt und $2 \mathrm{~h}$ post partum war größer $(\mathrm{p}<0.01)$ und die $2 \mathrm{~h}$-Werte im Kapillarblut im Vergleich zur Kontrollgruppe signifikant niedriger $(2,1$ $\mathrm{mmol} / \mathrm{l}$ vs. $2,6 \mathrm{mmol} / 1$, SD $0,55 \mathrm{mmol} / 1$ vs. $0,45 \mathrm{mmol} /$
$1, \mathrm{p}<0.025$, figure 1). Wir sahen eine signifikante Korrelation zwischen der pro Stunde infundierten Glukosemenge und den maternalen Spiegeln $(r=0.47)$ bzw. den Spiegeln im Nabelschnurblut $(r=0.61)$. Eine Hypoglykämie wurde definiert als Blutglukosespiegel $\leq 2.2$ $\mathrm{mmol} / 1$ und trat in $61 \%$ auf (14 von $23 \mathrm{Kindern})$, während sie in der Kontrollgruppe nur in $22.7 \%$ (5 von 22 Kindern) beobachtet wurde ( $p<0.025$, figure 2). Der mittlere ENNS-Score war in beiden Gruppen vergleichbar. Eine Analyse von gepoolten ENNS-Daten zeigte, daß hypoglykämische Episoden mit einem signifikant niedrigeren Score hinsichtlich des Muskeltonus und einem höheren Score hinsichtlich des Moro-Reflexes u. a. Parameter einhergehen $(p<0.05-0.001$, figure 3). Um die Langzeiteffekte dieser mit Hypoglykämien assoziierten frühen neurologischen Auffälligkeiten zu erfassen, sind weitere Untersuchungen notwendig. Unsere Ergebnisse zeigen deutlich, daß es bei Kindern, deren Mütter vor einer normalen Entbindung Glukoseinfusionen erhalten haben, ein erhöhtes Hypoglykämierisiko gibt. Bei solchen Kindern sollte routinemäßig die Bestimmung der Blutglukose erfolgen, um Hypoglykämien aufzudecken und zu behandeln.

Schlüsselwörter: Glukose, Glukoseinfusion, Hypoglykämie, Neugeborenes, neurologischer Status.

\section{Résumé}

Effets de l'apport de glucose à la mère en perpartum sur la glycémie néonatale et l'état neurocomportemental des nouveaux-nés à terme hypoglycémiques

On a dosé les taux de glucose dans le sang maternel et au sang du cordon au moment de l'accouchement ainsi qu'au niveau du sang capillaire (talon) à une et deux heures de vie chez 45 enfants à terme afin d'étudier l'effet de l'apport de glucose à la mère avant un accouchement normal sur l'équilibre glucidique des nouveaux-nés. Les mères de 23 enfants ont eu une perfusion intraveineuse de glucose avant l'accouchement (groupe étudié), tandis que les mères de 22 autres enfants n'ont subi, ni perfusion de glucose ni d'autres substance (groupe contrôle). On a également étudié l'état neurocomportemental de ces enfants à 1 et à 2 heures de vie, en se servant de l'échelle neurocomportementale néonatale précoce (ENNS) de SCARLON.

Les enfants du groupe étudié en comparaison avec ceux du groupe contrôle présentent un taux moyen de glucose au sang du cordon significativement plus élevé [groupe étudié: 6,5 (DS 2,1) mmol/1; groupe contrôle: 3,7 (DS $0,9) \mathrm{mmol} / \mathrm{l} ; \mathrm{p}<0,001$ ], une baisse plus importante des taux entre la naissance et deux heures de vie $(p<0,01)$, et des taux de glucose à 2 heures inférieurs [groupe étudié 2,1 (DS 0,55$) \mathrm{mmol} / 1$; groupe contrôle 2,6 (DS $0,45) \mathrm{mmol} / \mathrm{l} ;(\mathrm{p}<0,025)$ ] (figure 1). On a trouvé une corrélation significative entre la quantité de glucose perfusée à la mère par heure et les taux de glucose dans le sang maternel et au sang du cordon $(r=0,47$ et 0,61 respectivement). Une hypoglycémie, définie par une glycémie inférieure ou égale à $2,2 \mathrm{mmol} / 1$ a été mise en évidence chez $61 \%(14 / 23)$ des enfants du groupe étudié, alors qu'elle n'est retrouvée que dans $22,7 \%$ (5/22) des enfants controles $(p<0,025)$ (figure 2).

Les scores ENNS moyens sont similaires dans les deux groupes. Une analyse des données des ENNS poolés, en tenant compte de la glycémia, a révélé que les épisodes hypoglycémiques (glycémie $\leq 2,2 \mathrm{mmol} / \mathrm{l}$ ) s'accompa- 
gnent d'un score du tonus musculaire significativement inférieur et d'un score supérieur de l'extinction de la réponse de Moro ainsi que d'une diminution de la réponse à la lumière et à la piqûre d'épingle $(\mathrm{p}<0,05$ - 0,001) en comparaison du score lorsque l'état glucidique est normal (glycémie $\geq 2,3 \mathrm{mmol} / \mathrm{l}$ ) (figure 3 ). D'autres études sont necessaires pour évaluer la signification à long terme de ces anomalies neurocomportementales précoces accompagnant l'hypoglycémie. Nos données seggèrent fortement une augmentation du risque d'hypoglycémie chez les enfants à terme dont la mère $\mathrm{a}$ eu une perfusion de glucose avant un accouchement normal. Il faudrait en routine surveiller la glycémie de ces enfants afin de dépister et de traiter précocément une hypoglycémie.

Mots-clés: Glucose, hypoglycémie, neurocomportement, nouveau-né, perfusion de glucose.

Acknowledgements: I gratefully acknowledge the support of Labour ward Sister, Nursing Staff and residents who helped in conduct of the study, and Dr. E. Chookang, Sr. Lecturer, Dept. of Pathology, who measured blood glucose levels.

\section{References}

[1] ANDERSEN O, J Hertel, L SCHMOLKER: Influence of maternal plasma glucose concentration at delivery on possible risk of hypoglycemia in infants of insulin dependent diabetic mother. Acta Paediar Scand 74 (1985) 268

[2] BEARD R, R TURNER, N OAKLEY: Fetal response to glucose loading: fetal blood glucose and insulin response to hyperglycemia in normal and diabetic pregnancy. Postgrad Med 47 (1971) 68

[3] BOWIE MD, PB Mulligan, R SchWARTZ: Intravenous glucose tolerance in normal newborn infant: the effect of double dose of glucose and insulin. Pediatrics 31 (1963) 590.

[4] ChEz RA: Development and function of the human endocrine pancrease. In: JAFFE RB. The Endocrine milieu of pregnancy, puerperium and childhood, Report of Third Ross Conference on Obstetric Research, Ross Lab, Columbus, Ohio, 1974

[5] Cordero L, JA Grunt, GG ANDerson: Hypertonic glucose infusion during labour. Am J Obstet Gynecol 15 (1970) 560

[6] CoRnblath M, AF Ganzon, D Nicolopoulos: Studies of carbohydrate metabolism in newborn infant. III. Some factors influencing the capillary blood sugar and the response to glucagon during first hours of life. Pediatrics 27 (1961) 378

[7] CoRnblath M, R SchwartZ: Disorders of carbohydrate metabolism in infancy, 2nd ed. WB Saunders, Philadelphia, 1976

[8] Dumoulin JG, JEB Foulkes: Ketonuria during labour. Br J Obstet Gynaecol 91 (1984) 97

[9] Grasso S, G Palumbo, S Rugolo, A Cianci, G TumINo, G REITANO: Human fetal insulin secretion in response to maternal glucose and leucine administration. Pediatr Res 14 (1980) 782

[10] Grasso S, D Falluca, L Mazzone, L GiANGRANDE, G ROMEA, G REITANO: Inhibition of glucagon secretion in human newborn by glucose infusion. Diabetes 32 (1983) 489
[11] Kenepp N, S Kumar, WC Shelly, CA Stanley, SG GABBE, BB GUTSCHE: Fetal and neonatal hazards of maternal hydration with $5 \%$ dextrose before caesarean section. Lancet 1 (1982) 1150

[12] KETTERINGHAM RC, BR AuSTIN: Induced hyperglycemia at delivery. Am J Obstet Gynaecol 37 (1939) 1000

[13] Ktorza A, MT Bihoreau, N Nurjhan, L Picon, J GIRARD: Insulin and glycogen during the perinatal period: Secretion and metabolic effects on liver. Biol Neonate 48 (1985) 204

[14]LaWrence GF, VA Brown, RJ Parsons, ID CoOKe: Feto-maternal consequences of high dose glucose infusion during labour. Br J Obstet Gynaecol 89 (1982) 27

[15] Lucas A, TE Adrian, A Aynsley-Green, SR BLooM: Iatrogenic hyperinsulinism at birth. Lancet 1 (1980) 144

[16] Mendiola J, LJ Grylack, JW Scanlon: Effect of intrapartum glucose infusion on the normal fetus and newborn. Anesth Analg 61 (1982) 32

[17] Obenshain SS, P Adam, KC King, K Teramo, KO RaIvio, N RhaiA, R Schwartz: Human fetal insulin response to sustained maternal hyperglycemia. N Engl J Med 283 (1970) 566

[18] Scanlon JW, MV Brown, JB Weiss JB, MH ALPER: Neurological response of newborn infants after maternal epidural anaesthesia. Anesthesiology 40 (1974) 121

[19] Sexson WR: Incidence of neonatal hypoglycemia. A matter of definition. J Pediatr 105 (1984) 149

[20] Singhi S, E Chookang, St JE Hall, S Kalghatgi: Iatrogenic neonatal and maternal hyponatremia following oxytocin and aqueous glucose infusion during labour. Br J Obstet Gynaecol 92 (1985) 356

[21] Singhi S, E Chookang, St JE Hall: Intrapartum infusion of aqueous glucose solution, transplacental hyponatremia and risk of neonatal jaundice. $\mathrm{Br} \mathrm{J}$ Obstet Gynaecol 91 (1984) 1014 
[22] Singhi S, E Chookang: Maternal fluid overload during labour; transplacental hyponatremia and risk of transient neonatal tachypnoea in term infants. Arch Dis Child 59 (1984) 1155

[23] TaRnow-Mordi WO, JCL Shaw, D Lin, DA GARDNER, FV FLYNN: Iatrogenic hyponatremia of newborn due to maternal fluid overload; a prospective study. Br Med J 283 (1981) 639
[24] ToBIN JD, JF Roux, JS Soeldner: Human fetal insulin response after acute maternal glucose administration during labour. Pediatrics 44 (1969) 668

Received October 12, 1987. Accepted November 30, 1987.

Sunit Singhi, M. D.

Associate Professor

Department of Pediatrics

Postgraduate Institute of Medical

Education \& Research

Chandigarh-160012, India 